\title{
都市空間の再編とジェントリフィケーション \\ Gentrification and the Restructuring of Urban Space
}

\author{
下村恭広 \\ Yasuhiro SHIMOMURA
}

この特集は、第33回大会におけるテーマ部会「都市空間再編とジェントリフィケーショ ン」（2015年 9 月 13 日）での三つの報告に基づく論文で構成されている。はじめに、この 企画の経緯について振り返つておきたい。この数年のシンポジウムやテーマ部会では、大 都市圈における人口の都心回帰とその政治的含意について議論が続いている。前回大会の シンポジウム「都市中間層と居住空間の再編」（2014年 9 月 12 日）は、都心回帰について 都市中間層の居住選択と関わらせて捉え、社会階層的な視点の導入を試みた。この時に居 住空間の再編についていくつかの論点が出されたが、なかでもジェントリフィケーション にはたびたび言及がなされ、それをどのように理解すべきか論じられている。これを通じ て浮かび上がった課題のひとつが、「欧米のジェントリフィケーションと日本でジェント リフィケーションと呼ばれる現象において、何が同じで、何が違うのかをきちんと実証す る必要性」[原田 2015：4] である。本特集の元となったテーマ部会の企画は、この時のフ ロアからの問題提起への応答として始まった。

本特集で藤塚論文が示している通り、ジェントリフィケーションは英語圈を中心に広く 国際的に共有され、研究蓄積の進んだテーマである。それに対して日本の都市社会学で は、本特集の高木論文が振り返るように個別の調査研究があるにもかかわらず、学会とし て十分な検討を与えられてきた概念とは言い難い。ひとまずこのテーマを、特定の地域の 住民が居住環境の改善を伴いつつより高い社会階層へ入れ替わつていく過程を批判的に捉 える試みであり、それが生じる要因について政治経済的あるいは社会文化的な観点から分 析しようとするさまざまなアプローチを包括するものとしておこう。テーマ部会ではこの 概念が提示している視角について確認し、この概念を用いることで現在の都市で進んでい る過程の理解がより深まるのか、またこれまでの対象の捉え方がどのように変わりうるの か、都市研究におけるその意義について明らかにすることを目指した。

当日は第一報告として藤塚吉浩氏（大阪市立大学）から、地理学の立場で国際的な研究 蓄積の概略と、現在の研究のフロンティアが提示された。次に第二報告として高木恒一会 員（立教大学）に、ジェントリフィケーションの構造的要因としての都市政策について、 
東京を事例に論じていただいた。最後に第三報告として山本薰子会員（首都大学東京）に よって、ジェントリフィケーションの引き起こす社会問題が、バンクーバーの都市下層地 域の事例に基づいて検討された。また討論者として、政治経済的な側面を重視した研究を 手がけ、人口の都心回帰の調査を進めている丸山真央会員（滋賀県立大学）と、都市のセ グリゲーションについて国際比較を行い、特にフランスの都市の状況に詳しい川野英二会 員（大阪市立大学）にコメントをいただいた。

ここで特集の各論文の概要を確認しておこう。藤塚論文は、1990年代以降のジェントリ フィケーションの研究動向について、論文数の推移や研究対象地域の拡散を分野横断的に 概観している。あわせて最初にジェントリフィケーションが問題化した都市であるロンド ンについて、そこでいわれるジェントリフィケーションの内実が当初とはかなり変質しつ つあることが指摘される。それはフロンティアの地理的拡大、ジェントリファイアーの属 性の変化、新築のジェントリフィケーションの顕在化であり、これらは都市政策の影響に よるところが大きい。我々の問題関心の出発点においては欧米と日本との対置を前提とし ていたが、実のところ欧米のジェントリフィケーション論でも進んでいる概念の拡張と地 理的拡散とを踏まえた認識が求められているのである。

続く高木論文では、1990年代後半以降の東京を対象に、都心への人口回帰について、国 の「都市再生」政策と、東京都の「環状メガロポリス構想」と関連づけて捉え直される。 これは著者が1990年代初頭に調査していた都心再開発の事例から、そのコンテクストに 大きな変化が進んだことを意味する。ここで描かれた社会一空間構造の転換と 1990 年代 後半以降の東京都心におけるジェントリフィケーションとの結び目にあるのは、社会政策 としての側面を後退させながら都心居住が推進される住宅政策である。神宮外苑の国立競 技場の建て替えに合わせた都営霞が丘アパートの住民立ち退きは、まさにこの問題領域が 顕在化した事態といえよう [稲葉 2015]。

最後に山本論文は、バンクーバーの都市下層地域が見せている変化と、そこでの市民運 動団体や住民諸階層の対応の多義性を明らかにした事例研究である。この地域では低家賃 住宅の減少と中間階級向けの商店や飲食店の新規開業が進んでいるが、それらはまぎれも なくジェントリフィケーションとして告発される対象である。同時に、地域経済の活性化 による住民の雇用創出につながるチャンスとして期待されるところもあり、その評価をめ ぐって運動団体や住民間で亀裂が露わとなつた。地域経済の活性化は、地域に住む最も困 難な人々の排除につながらない形態で実施することが果たして可能なのか。模索が続けら れているなかで、ジェントリフィケーションへの対抗は多様化している。

以上の諸論考が追究している問題について、既存のジェントリフィケーション論と対比 して位置づけてみたい。ジェントリフィケーションが起きる過程の説明として、現在最も オーソドクスな位置づけにあるのは、ニール・スミスの地代格差論であろう [Smith 1996 $=2014]$ 。スミスは都市空間の変動を資本蓄積過程として捉え、ジェントリフィケーショ 
ンを説明する要因として、インナーシティで生じた地代格差に着目している。地代格差 は、土地・建物が適切に利用されている時に得られるはずの地代と実際の地代とのギャッ プがある状況で、それが投資のチャンスとして認識される。ジェントリフィケーション は、他の投資先の利潤率が低下したタイミングに、このギャップが十分に拡大している場 所において誘発されるのである。まず考えておかねばならないのは、ここで地代格差が生 じる場所についての理解だ。初期になされた研究の多くは、インナーシティに地代格差を 見出してきた。その認識は、脱工業化が進んでいた当時の英語圏における都市の空間構造 に根差している。しかし藤塚論文が示すように、ジェントリフィケーションが進むことに よって都市の空間構造が変わり、そのフロンティアもまた当初から大きく移り変わってい る。ここで思い起こされるのは、テーマ部会の当日の議論で討論者の丸山会員が指摘し た、ジェントリフィケーションという概念を導入することの認識利得を明確にする必要性 である。これについて高木会員からは、コミュニティ研究では前提として以上には焦点化 されることの少ない、都市の空間構造の変化を問題にする点にあると強調された。さらに いえばそれは、藤塚氏が明らかにしたように社会階層的に構造化された都市空間である。 そして、空間構造がごのように社会構造とつながっているのかは都市によって一様ではな い。ジェントリフィケーションの発現形態は、このような都市の社会構造と空間構造の結 びつき方によって変わってくる。高木論文が促す住宅政策の検討は、東京を対象とした研 究におけるこの両者の結びつき方の解明に関わつてくるのである。

加えてもうひとつ重要なのが、各都市に固有の地域政治のコンテクストを議論にどのよ うに組み込むかという問題である。特に注目したいのは、山本論文が分析しているよう な、ジェントリフィケーションへの対抗運動の持つ意味である。当日の議論で討論者の川 野会員から指摘されたように、そもそもジェントリフィケーションが認識され、社会問題 として成立するかどうかは、社会運動のつくりだす文脈に依拠している。ジェントリフィ ケーションは、住民の追い出しや地域社会の崩壊を不当と捉え、抵抗が組織化されるとき に、告発のための用語として用いられてきた。たとえばフランスでは長く、ジェントリ フィケーションにあたる事実に対しては、embourgeoisementという用語が使われていた。 しかしこの言葉には労働者階級の地域住民の富裕化というニュアンスも含まれ、告発やそ のための分析に使える概念ではない。そのために近年は、ジェントリフィケーションとい う英語が急速に普及したのである。

これらを踏まえると、日本の都市社会学でジェントリフィケーションが争点としては不 在に見えた状況も、実は同様の問題関心に基づきながら、異なる概念や理論的・社会的文 脈を前提にした経験的研究が続いてきた可能性もある。日本におけるジェントリフィケー ションを理解するには、日本の都市構造再編について 1980 年代までさかのぼり、それを めぐる当時の政治的争点の浮かび上がり方や、各種言説の布置状況も含めて再検討する必 要があるだろう。これは引き続き次年度のシンポジウムのテーマとして取り組んでいくこ 
ととしたい。

\section{参考文献}

原田 謙, 2015, 「特集解題 : 都市中間層と居住空間の再編」『日本都市社会学会年報』33：1-4. 稲葉奈々子, 2015, 「東京オリンピックと都営霞が丘アパート」『寄せ場：日本寄せ場学会年報』 $27: 61-75$.

Smith, Neil, 1996, The New Urban Frontier: Gentrification and the Revanchist City, Routledge. (=原 口剛訳，2014，『ジェントリフィケーションと報復都市』ミネルヴァ書房.）

(しもむら やすひろ／玉川大学リベラルアーツ学部准教授) 